\title{
Originals
}

\section{Insulin Binding, Insulin Degradation and Glucose Metabolism in Human Monocytes}

\author{
H. Beck-Nielsen and O. Pedersen \\ Medical Department III and Department of Clinical Chemistry, County Hospital, Aarhus, Denmark
}

\begin{abstract}
Summary. Insulin binding, insulin degradation and glucose metabolism were studied in highly purified preparations of monocytes. Steady state specific insulin binding was found at $15^{\circ} \mathrm{C}$, whereas no plateau was reached at $37^{\circ} \mathrm{C}$ because of considerable insulin degradation at this temperature. ${ }^{125} \mathrm{I}$-insulin nonspecifically bound to monocytes at $15^{\circ} \mathrm{C}$ remained constant for $120 \mathrm{~min}$. In contrast non-specifically bound ${ }^{125} \mathrm{I}$-insulin increased during incubation at $37^{\circ} \mathrm{C}$. About one third dissociated slowly to a washout medium suggesting an intracellular uptake of this fraction of non-specifically monocyte bound insulin. Monocytes did not degrade insulin at $15^{\circ} \mathrm{C}$. At $37^{\circ} \mathrm{C}$ insulin was degraded partly by "proteases" released from the cells and partly by the specific insulin receptor. We found that about $35 \%$ of the total monocyte receptor bound iodoinsulin dissociated to a washout medium as degraded insulin. Furthermore, the degradation velocity of receptor bound insulin was proportional to the receptor occupancy. Thus, at $37^{\circ} \mathrm{C}$ receptor bound insulin is the substrate for insulin degradation in monocytes and the reaction between the insulin molecule and the insulin receptor is conceivably considered not to be bimolecular at $37^{\circ} \mathrm{C}$ unlike at $15^{\circ} \mathrm{C}$. Previously, no biological effect of insulin on monocytes has been demonstrated. In this study we found that insulin increased glucose uptake $(25 \%, \mathrm{p}<0.01)$ and lactate release $(12 \%$, $\mathrm{p}<0.05)$ in monocytes with $\mathrm{ED}_{50}$-values within the physiological range. To obtain $50 \%$ of maximal biological effect it was necessary to activate only a few percent of the receptors.
\end{abstract}

Key words: Insulin receptors, insulin degradation, glucose and lactate metabolism, monocytes, lymphocytes and mononuclear leucocytes.
Mononuclear leucocytes have been used extensively for insulin binding studies in man. The major part of insulin binding to mononuclear cells is accounted for by the monocytes $[1,2]$. Previously, it has not been technically possible to isolate pure preparations of monocytes. In this study we have measured insulin binding to almost pure preparations of monocytes and lymphocytes, respectively, in order to estimate the ratio between insulin binding to monocytes and lymphocytes; it has previously been assumed that this ratio is constant [2]. In monocytes the time course of total and non-specific cell binding and the nature of non-specific cell binding at $15^{\circ} \mathrm{C}$ and $37^{\circ} \mathrm{C}$ have been studied.

Degradation of insulin has generally been assumed to be independent of insulin binding to the specific membrane receptor [3]. Terris and Steiner [4] found, however, that insulin binding and insulin degradation in hepatocytes were closely related. We have therefore examined the relationship between insulin binding and insulin degradation in monocytes.

Despite a high insulin binding capacity of monocytes no biological effect of insulin has been previously observed in these cells. Using purified preparations of monocytes we have also studied the effect of insulin on monocyte glucose metabolism.

\section{Material and Methods}

Young (20-28 years old) healthy persons with normal body weight (90-110\% of ideal weight) were examined. Sixty per cent of the volunteers were women. None of them took any drugs during the study period. Informed consent was obtained from all subjects.

\section{Preparations of Cells}

Mononuclear leucocytes were isolated from $100-150 \mathrm{ml}$ blood drawn from a antecubital vein at $0800 \mathrm{~h}$ after an overnight fast. The blood was collected in tubes containing EDTA (dipotassium 
salt) $30 \mathrm{~g} / 100 \mathrm{ml}$ and the cells were fractionated on Lymphoprep (Na-metrizoate from Nyegård, Oslo) gradients according to Boyum [5]. Isolates contained 15-25\% monocytes, 75-80\% lymphocytes, about $1 \%$ granulocytes and a variable number of platelets and erythrocytes [2].

Monocytes were isolated by resuspending the mononuclear leucocytes in RPMI-1640 medium containing $50 \mathrm{~g} / \mathrm{l}$ bovine serum albumin (BSA), penicillin $5 \mathrm{U} / \mathrm{l}$, streptomycin $0.5 \mathrm{ug} / \mathrm{l}$, L-glutamine $200 \mathrm{mmol} / 1$, and Hepes (N-2-hydroxy-ethylpiperazine-N-2ethane-sulphonic acid) $25 \mathrm{mmol} / \mathrm{l}$. Suspensions of $4 \times 10^{6}$ cells per $\mathrm{ml}$ were incubated for 2 hours at $37^{\circ} \mathrm{C}$ in petri dishes. During incubation monocytes adhere to the bottom of the dishes.

After removal of non-adherent cells, dishes were washed at $37^{\circ} \mathrm{C}$ with Hanks balanced salt solution (HBSS) containing $50 \mathrm{~g} / 1$ BSA. Chilled HBSS containing $5 \mathrm{~g} / \mathrm{l}$ BSA was then added to the dishes and the adherent cells were gently removed with a gum stick. The released cells were washed twice at $20^{\circ} \mathrm{C}$ and resuspended in HBSS containing $5 \mathrm{~g} / 1 \mathrm{BSA}$ at a concentration of about $10^{6}$ cells $/ \mathrm{ml}$. Twenty $\mathrm{ml}$ of the suspension was layered over $10 \mathrm{ml}$ of a suspension of one part $14 \%$ ficoll/isopaque and one part Lymphoprep in a centrifuge tube. By centrifugation at $2000 \mathrm{~g}$ for 20 min dead cells were spun to the bottom. Cells layered in the interphase were harvested and after washing resuspended in the incubation buffer [6].

Monocytes were identified by morphological and cytochemical criteria in cytocentrifuged smears using an alpha naphthyl acetate esterase method [7]. Monocytes comprised 79\% $\pm 9 \%$ (mean \pm $\mathrm{SD})$ of total mononuclear leucocytes in the suspension $(\mathrm{n}=27)$. The contamination with granulocytes and erythrocytes was insignificant, but a variable number of platelets was present. Using the trypan blue exclusion test monocyte viability was about $95 \%$ [8].

Lymphocytes were isolated among the non-adherent cells of the petri dishes; $0.2 \mathrm{~g}$ carbonyl iron powder (Grade SF, GAF comp., New York) was added to $10 \mathrm{ml}$ cell suspension. After incubation at $37^{\circ} \mathrm{C}$ for $30 \mathrm{~min}$ phagocytic monocytes and granulocytes were removed with a magnetic stick [2]. The final lymphocyte suspension was contaminated with less than $1 \%$ monocytes. The ratio between erythrocytes and lymphocytes was $1: 3$, whereas the number of granulocytes and platelets was insignificant. The insulin binding capacity of erythrocytes is only $10 \%$ of that of lymphocytes [2]. Thus contamination of the lymphocyte suspension with erythrocytes is probably unimportant.

\section{Incubation Buffer}

A Hepes buffer was used in all incubation studies. The buffer contained in mmol/l: Hepes, $100 ; \mathrm{KCl}, 4.7 ; \mathrm{NaCl}, 80 ; \mathrm{MgSO}_{4}$, 1.2; $\mathrm{CaCl}_{2}, 2.5 ; \mathrm{NaH}_{2} \mathrm{PO}_{4}, 0.2 ; \mathrm{Na}_{2} \mathrm{HPO}_{4}, 1.0$; and glucose, 5 . Human albumin was present at $10-30 \mathrm{~g} / 1$. pH was 7.4 at $37^{\circ} \mathrm{C}$ and 7.8 at $15^{\circ} \mathrm{C}$. During incubation for $180 \mathrm{~min}$ at $37^{\circ} \mathrm{C} \mathrm{pH}$ of the medium dropped by 0.2 from the original $\mathrm{pH}$.

\section{Insulin Binding Studies}

${ }^{125}$ I-insulin iodinated and purified [9] by ion exchange chromatography to a specific activity of about $150 \mu \mathrm{Ci} / \mu \mathrm{g}$ was a gift from Novo Research Institute. About $90 \%$ of the iodoinsulin contained only one iodine atom per insulin molecule. The iodine atoms were attached to the tyrosine in the $\mathrm{A}_{19}$ position.

All cell types were incubated in duplicate with ${ }^{125} \mathrm{I}$-insulin at a concentration of $35 \mathrm{pmol} / 1(0.2 \mathrm{ng} / \mathrm{ml})$ in $100 \mathrm{mmol} / 1$ Hepes buffer. Incubation time and cell number concentration are given in the legends to the figures. For competition studies native insulin in increasing concentrations was added to the incubation medium. At the end of incubation $250 \mu \mathrm{l}$ cell suspension was added to a $1.5 \mathrm{ml}$ microtube containing $1.0 \mathrm{ml}$ icecold buffer. Cell bound and free insulin were separated by centrifugation in a Beckman microfuge for $1 \mathrm{~min}$. The cell-free supernatant (containing free ${ }^{125} \mathrm{I}$-insulin) was carefully aspirated and the cell pellet was washed twice with cold buffer. The tip of the microtube, which contained the cells with bound ${ }^{125} \mathrm{I}$-insulin, was excised and both free and cell-bound radioactivity was counted. Total cell binding indicates the radioactivity of the cell pellet. Non-specific cell binding is the radioactivity of the pellet in the presence of an excess of unlabelled insulin $\left(10^{-5} \mathrm{~mol} / \mathrm{l}\right)$. Specific cell binding is defined as the difference between total and non-specific binding. Specific cell binding is expressed as a fraction of the total radioactivity.

Binding Analysis. The results of the binding studies are presented in 3 ways:

1) The specific cell bound fraction of insulin at the tracer concentration ( $35 \mathrm{pmol} / \mathrm{l})$.

2) The specific cell bound fraction plotted as a function of total insulin concentration (competition curve).

3) The concentration of native insulin necessary to reduce the specific cell bound fraction of ${ }^{125} \mathrm{I}$-insulin at insulin tracer concentration $50 \%$ ( $50 \%$ inhibition) is for comparative studies taken as an estimate of apparent receptor affinity.

\section{Determination of Extracellular Trapped ${ }^{125}$ I-Insulin}

The fraction of iodoinsulin trapped extracellularly after separation of cell bound and free insulin was determined by ${ }^{14} \mathrm{C}$-L-glucose $(0.55 \mu \mathrm{Ci} / \mathrm{ml})$ incubation, specific activity: $61 \mathrm{Cl} / \mathrm{mol}$, for $1 \mathrm{~min}$ at $20^{\circ} \mathrm{C}$. The separation procedure was as described above. Radioactivity in the cell pellet was counted in a liquid scintillation counter.

\section{Degradation of ${ }^{125} \mathrm{I}$-Insulin}

The degradation of iodoinsulin was estimated by its solubility in $10 \%(\mathrm{w} / \mathrm{v})$ trichloracetic acid (TCA). The amount degraded was expressed as the percentage contribution to the total amount of ${ }^{125}$ I-insulin.

\section{Degradation of Labelled Insulin Dissociated from Monocytes}

Monocytes $\left(7 \times 10^{6} / \mathrm{ml}\right)$ were incubated in duplicate with ${ }^{125} \mathrm{r}$ insulin $(140 \mathrm{pmol} / \mathrm{l})$ for 1 hour at $37^{\circ} \mathrm{C}$. Cells were recovered and resuspended in $1 \mathrm{ml}$ washout buffer. ${ }^{125} \mathrm{I}$-insulin was allowed to dissociate into the washout medium for 1 hour at $37^{\circ} \mathrm{C}$. Then TCA was added to the medium after removing of cells. Using this method total degradation in the washout medium was determined.

Control experiments were carried out under the same conditions but without the presence of labelled insulin for the first hour of the incubation period, but after resuspension of monocytes in the washout medium labelled insulin was added in a concentration similar to the amount of insulin bound to cells in the parallel study. The incubation was continued for 1 hour and the fraction of ${ }^{125} \mathrm{I}$ insulin degraded was determined. ${ }^{125}$ I-insulin degraded at the receptor site is the difference between the fractions degraded in the two washout media.

In the time course studies for dissociation of degraded and non-degraded insulin the media degradation was inhibited by adding native insulin $\left(10^{-5} \mathrm{mmol} / \mathrm{l}\right)$ to the washout medium. Hence, no control experimenss were necessary in the lavier experiments. 
Specific cell bound fraction

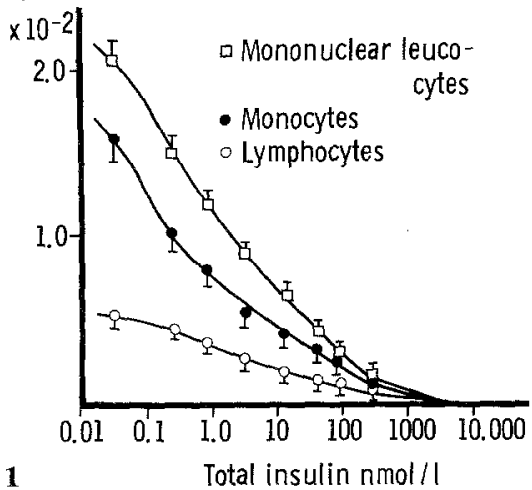

(4)

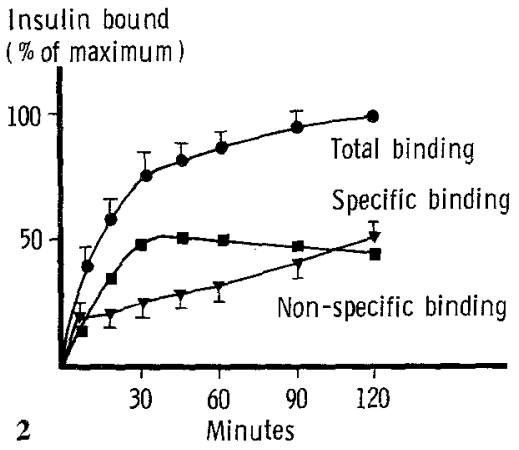

(B)

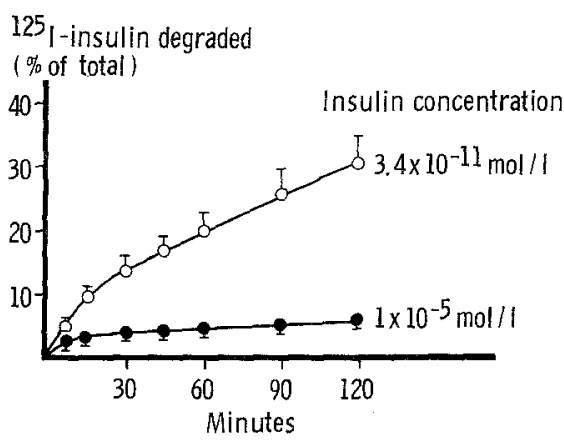

Fig. 1. Insulin binding to mononuclear leucocytes and highly purified preparations of monocytes and lymphocytes in normal subjects (mean \pm $\mathrm{SEM}, \mathrm{n}=10$ ). Insulin binding to cells in purified preparations of monocytes and lymphocytes from each person was adjusted to the concentration of these cells in the suspension of mononuclear leucocytes. The concentration of monocytes was $6.5 \times 10^{6} / \mathrm{ml}$ and of lymphocytes $35 \times 10^{6} / \mathrm{ml}$

Fig. $2 \mathbf{A}$ and B. Binding and degradation of ${ }^{125}$ I-insulin. In panel $\mathbf{A}$ total cell binding and non-specific cell binding at $37^{\circ} \mathrm{C}$ are plotted as functions of the incubation time (mean $\pm S E M, n=6$ ). Specific cell bound fraction is the difference between the two binding variables. Panel $\mathbf{B}$ shows ${ }^{125}$-I-insulin degraded, in percent of total radioactivity of the supernatant. Degradation of labelled insulin was tested by the precipitability of iodoinsulin in a $10 \%$ TCA solution

\section{Degradation of ${ }^{125}$ I-Insulin Taken up by the Cells}

The degradation of iodoinsulin taken up by monocytes was studied using TCA precipitability after insulin had been extracted by a solution of acetic acid $(3 \mathrm{~mol} / 1)$ and urea $(6 \mathrm{~mol} / 1)$ for 1 hour at $15^{\circ} \mathrm{C}$.

\section{Metabolic Effects of Insulin}

Glucose Uptake. Glucose uptake by monocytes was estimated comparing the glucose concentration in the medium at time zero with that at the end of the incubation. Medium glucose concentration was measured by the method of Feteris [10]. Cells were incubated in the Hepes buffer at $37^{\circ} \mathrm{C}$ for $90 \mathrm{~min}$ without and with increasing concentrations of insulin. A buffer glucose concentration of $2.5 \mathrm{mmol} / \mathrm{l}$ was used, because the optimal insulin effect was achieved at this concentration. The standard deviation (of replicates) for determination of glucose uptake was found to be $0.020 \mathrm{umol} / 3 \times 10^{6}$ monocytes $/ 90 \mathrm{~min}$.

Lactate Release. Subsequent to glucose uptake monocytes release lactate. The lactate release was measured comparing the lactate concentration in the medium at the end of incubation to that at zero time. Incubation conditions were identical to those described for glucose uptake. Lactate in the medium was measured enzymatically [12]. The standard deviation for determination of lactate release was found to be $0.033 \mu \mathrm{mol} / 3 \times 10^{6}$ monocytes/ $90 \mathrm{~min}$.

Determination of Water Space in Monocytes. Intracellular water space of monocytes was measured by the ${ }^{14} \mathrm{C}-3-0$-methyl-d-glucose uptake. Monocytes (about $5 \times 10^{6} / \mathrm{ml}$ ) were incubated with the tracer $(0.87 \mu \mathrm{Ci} / \mathrm{ml})$, specific activity: $59 \mathrm{Ci} / \mathrm{mol}$, for $30 \mathrm{~min}$ at $37^{\circ} \mathrm{C}$ with and without insulin $\left(10^{-8} \mathrm{~mol} / \mathrm{l}\right)$. Cells were separated from free ${ }^{14} \mathrm{C}-3-0$-methyl-d-glucose by centrifugation through silicone oil [2]. Radioactivity in the cell pellet was counted in a liquid scintillation counter.

\section{Statistical Methods}

Wilcoxon's test for paired differences was employed for comparison of glucose uptake and lactate release in the cells treated with and without insulin. The precision of the methods for determination of glucose uptake and lactate release was evaluated calculating the standard deviations of duplicates.

Spearman's coefficient of rank was applied in correlation studies.

\section{Results}

Insulin Binding to Suspensions of Mononuclear Leucocytes, Monocytes and Lymphocytes

Figure 1 shows that insulin binding to the mononuclear leucocytes of a heterogeneous cell suspension was similar to the total of insulin binding to monocytes and lymphocytes of the purified cell preparations. Monocytes bound significantly $(\mathrm{p}<0.01)$ more insulin than lymphocytes at each insulin concentration tested (Fig. 1). The amount of insulin necessary to reduce the specific ${ }^{125} \mathrm{I}$-insulin binding $50 \%$ was for monocytes about $1 \mathrm{nmol} / 1$ and for lymphocytes about $3 \mathrm{nmol} / \mathrm{l}$, suggesting a higher receptor affinity in monocytes. Scatchard plots [11] (not shown) were curvilinear and estimated from the intercept on the $x$ axis the number of insulin receptors on monocytes was about 10 times that of lymphocytes (about 19,000 versus 1,900 ).

In cell preparations from 10 normal persons the ratio between insulin binding to lymphocytes and 
monocyies was studied. We found ha: this ratio was fairly constant from person to person. At insulin tracer concentration the ratio $(\mathrm{k})$ was $0.063 \pm 0.012$ (mean $\pm \mathrm{SD}$ ). The value of $\mathrm{k}$ increased with increasing receptor occupancy $(\mathrm{k}=0.078 \pm 0.031$ at she highes: insulin concen iration tested, Fig. 1).

\section{Specific Insulin Binding, Non-Specific}

Insulin Binding and Insulin Degradation

A maximum of specific insulin binding to monocytes in purified suspensions was reached after $30 \mathrm{~min}$ at $37^{\circ} \mathrm{C}$ (Fig. 2) and after $80 \mathrm{~min}$ at $15^{\circ} \mathrm{C}$ (Table 1). At $15^{\circ} \mathrm{C}$ the binding level was maintained for further $40 \mathrm{~min}$ (Table 1), whereas the binding decreased in time at $37^{\circ} \mathrm{C}$ (Fig. 2). Non-specifically bound insulin

Table 1. Time course for ${ }^{125} \mathrm{I}$-insulin binding to monocytes at $15^{\circ} \mathrm{C}$. Total cell binding and non-specific binding are plotted as functions of incubation time. Specific cell binding fraction is the difference between the two binding variables. Binding values are given as percentage of maximal binding ( $t=120 \mathrm{~min}$, for total binding). Mean values of 3 experiments are shown

\begin{tabular}{lcccccc}
\hline & \multicolumn{2}{l}{ Minutes } & & & & \\
\cline { 2 - 7 } & 2 & 15 & 30 & 60 & 90 & 120 \\
\hline $\begin{array}{l}\text { Total } \\
\text { binding }\end{array}$ & $20 \%$ & $55 \%$ & $75 \%$ & $90 \%$ & $100 \%$ & $100 \%$ \\
$\begin{array}{l}\text { Non-specific } \\
\text { binding }\end{array}$ & $10 \%$ & $12 \%$ & $10 \%$ & $12 \%$ & $14 \%$ & $13 \%$ \\
$\begin{array}{l}\text { Specific } \\
\text { binding }\end{array}$ & $10 \%$ & $43 \%$ & $65 \%$ & $78 \%$ & $86 \%$ & $87 \%$ \\
\hline
\end{tabular}

averaged $12 \%$ of maximally bound insulin at $15^{\circ} \mathrm{C}$ and was constant (Table 1). At $37^{\circ} \mathrm{C}$ the non-specifically bound fraction increased as a function of time (Fig. 2) from $18 \%$ at 2 min to $50 \%$ after 2 hours. At $37^{\circ} \mathrm{C}$ enhanced degradation of ${ }^{125} \mathrm{I}$-insulin in the incubation medium was also found (Fig. 2B). Addition of excess insulin reduced degradation of the labelled insulin (Fig. 2B), but the degradation still increased slightly with time. Degradation was constant and insignificant $(5 \%)$ at $15^{\circ} \mathrm{C}$ (not shown).

Figure $3 \mathrm{~A}$ shows how non-specifically bound ${ }^{125} \mathrm{I}$-insulin at $15^{\circ} \mathrm{C}$ and $37^{\circ} \mathrm{C}$, respectively, dissociated into a washout medium. Iodoinsulin non-specifically bound at $15^{\circ} \mathrm{C}$ dissociated immediately to the washout medium. Only about $5 \%$ was still "bound" after $5 \mathrm{~min}$. At $37^{\circ} \mathrm{C}$, however, only $2 / 3$ of non-specifically bound iodoinsulin was released after $5 \mathrm{~min}$. Figure $3 \mathrm{~B}$ shows that about $20 \%$ of non-specifically bound iodoinsulin dissociated to the washout medium was degraded after 1 hour. To determine the contribution of extracellulary trapped ${ }^{125}$ I-insulin to the amount of non-specifically bound insulin, we measured the ${ }^{14} \mathrm{C}-\mathrm{L}$-glucose distribution "space". Using this method we found at $15^{\circ} \mathrm{C}$ that about $10 \%$ of non-specifically bound ${ }^{125} \mathrm{I}$-insulin was attributable to extracellularly trapped radioactivity.

\section{Mechanism of Insulin Degradation}

Comparison of Degradation of Prebound and Not Prebound Insulin. The degradation of prebound and not prebound ${ }^{125} \mathrm{I}$-insulin at $37^{\circ} \mathrm{C}$ was studied. Forty

\section{A}

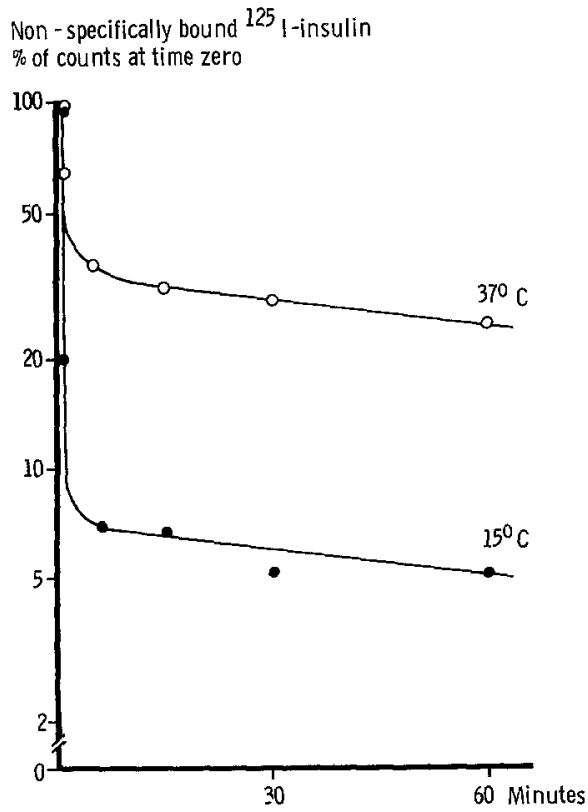

B

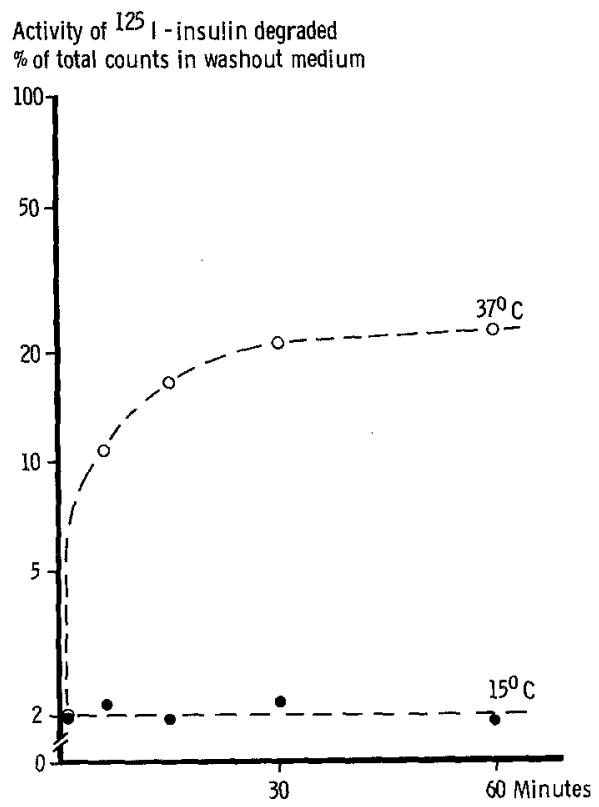

Fig. $3 \mathrm{~A}$ and B. Release of non-specifically bound ${ }^{125}$ I-insulin to a washout medium. Panel A shows the release of non-specifically bound 125 I-insulin to a washout medium (at $15^{\circ} \mathrm{C}$ ) containing $10^{-5} \mathrm{~mol} / 1$ native insulin (mean \pm SEM, $n=5$ ). Monocytes concentration was $5 \times$ $10^{6} / \mathrm{ml}$. Panel $\mathbf{B}$ shows the degradation of released ${ }^{125} \mathrm{I}$-insulin as a function of time 
two percent of receptor bound ${ }^{125} \mathrm{I}$-insulin dissociated to the washout medium was TCA soluble after 1 hour. In control experiments (no prebound iodoinsulin) monocytes were incubated with labelled insulin at a concentration similar to that of the washout medium following dissociation of ${ }^{125} \mathrm{I}$-insulin bound to the receptors. Under such conditions insulin binding to its receptor is insignificant. Only $12 \%$ of this labelled insulin was degraded. An identical fraction was degraded when ${ }^{125} \mathrm{I}$-insulin was incubated with the cell free supernatant from the control experiment.

\section{Time Course for Dissociation of Receptor Bound Insulin}

${ }^{125} \mathrm{I}$-insulin bound to monocytes was allowed to dissociate to a washout medium containing excess unlabelled insulin $\left(10^{-5} \mathrm{~mol} / \mathrm{l}\right)$, which should totally inhibit insulin degradation in the medium. Insulin was released into the medium in two components, one soluble in TCA and one precipitable in TCA (Fig. 4). The half-time for release was similar for the two components. After dissociation for 1 hour the TCA soluble component averaged $35 \%$ of total radioactivity.

Degradation of Receptor Bound Insulin as a Function of Receptor Occupancy. Corrected for non-specifically bound ${ }^{125} \mathrm{I}$-insulin, the percentage of radioactivity released in a TCA soluble form (degraded ${ }^{125} \mathrm{I}$ insulin) was independent of the occupancy in a concentration range of $0.2-66.0 \mathrm{nmol} / \mathrm{l}$ insulin. The fraction of degraded insulin was about $36 \%$. Thus, binding and degradation of ${ }^{125} \mathrm{I}$-insulin were proportional.

Acid Extraction of Iodoinsulin Taken up by the Cells. By acid extraction of ${ }^{125}$ I-insulin taken up by monocytes at $37^{\circ} \mathrm{C}$ we found that the recovery of radioactivity was near to $100 \%$ and about $10 \%$ of ${ }^{125}$ I-insulin extracted was degraded. On the other hand less than $5 \%$ of iodoinsulin extracted from cells incubated with tracer plus native insulin $\left(10^{-5} \mathrm{~mol} / \mathrm{l}\right)$ was degraded. At $15^{\circ} \mathrm{C}$ all insulin extracted was nondegraded.

\section{Insulin Effects on Monocytes}

Glucose uptake and lactate release were measured in suspensions of purified monocytes isolated from 17 subjects. Positive correlations were found between the two components measured and the monocyte concentration $(\mathrm{R}=0.84, \mathrm{p}<0.001$ and $\mathrm{R}=0.83$, $\mathrm{p}<0.001$, respectively).

Figure 5 shows a linear glucose uptake and lactate

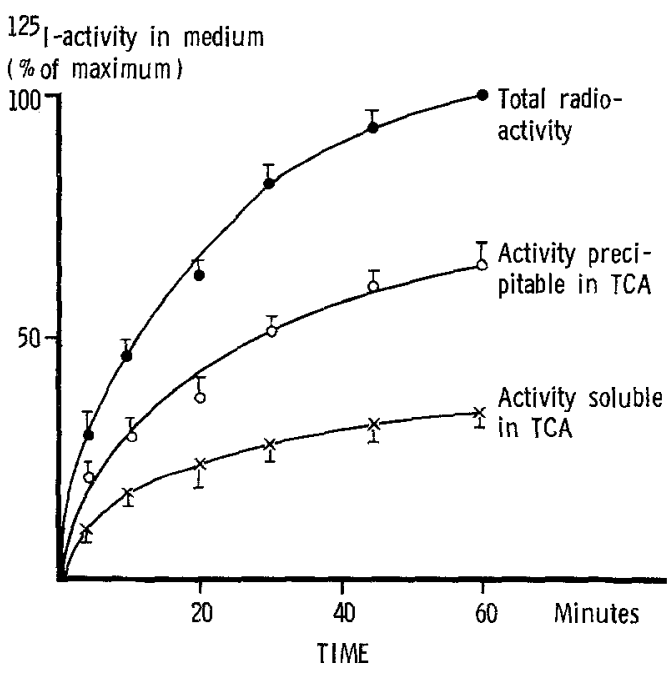

Fig. 4. Dissociation of receptor bound ${ }^{125}$ I-insulin to a washout medium. Dissociation of degraded and non-degraded ${ }^{125} \mathrm{I}$-insulin from monocytes $\left(5 \times 10^{6} / \mathrm{ml}\right)$ was studied (mean $\pm \mathrm{SEM}, \mathrm{n}=3$ ). The values were corrected for non-specifically bound iodoinsulin, which averaged $45 \%$ of total binding. At time $60 \mathrm{~min}$ more than $90 \%$ of receptor bound ${ }^{125} \mathrm{I}$-insulin was dissociated
A



B



Fig. $5 \mathbf{A}$ and B. Time course for glucose uptake and lactate release in monocytes. Monocyte suspensions $\left(5 \times 10^{6} / \mathrm{ml}\right)$ were incubated at $37^{\circ} \mathrm{C}$ without $(-0)$ and with $(\mathrm{O}-\mathrm{O})$ insulin, $10^{-8} \mathrm{~mol} / \mathrm{l}$. Initial glucose concentration was $2.5 \mathrm{mmol} / 1$. Glucose uptake $\mathbf{A}$ and lactate release $\mathbf{B}$ are shown

release in isolated monocytes during $90 \mathrm{~min}$. An enhancement both of glucose uptake and lactate release was induced by insulin. This effect was not caused by an increase in the monocyte water space as the total 3-0-methyl-d-glucose equilibrium space of monocytes was not influenced by insulin [mean \pm SD of 6 replicates: $2717 \pm 224 \mathrm{cpm} / 5 \times 10^{6}$ monocytes (basal) and $2793 \pm 350 \mathrm{cpm} / 5 \times 10^{6}$ monocytes (plus insulin, $10^{-8} \mathrm{~mol} / \mathrm{l}$ )]. 
(A)

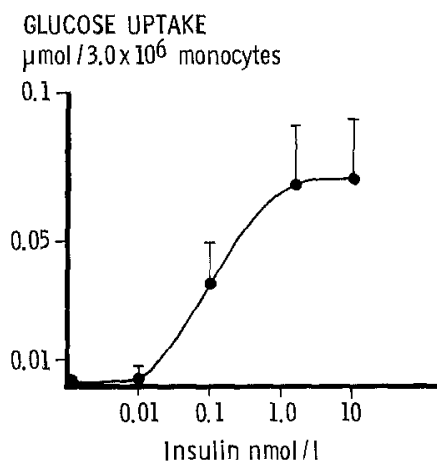

(B)

LACTATE PRODUCTION
$\mu$ mol $/ 3.0 \times 106$ monocyte

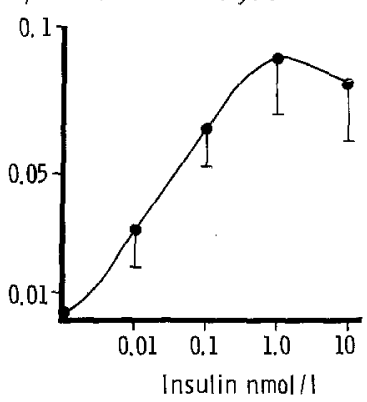

Fig. 6A and B. Insulin dose-response curves for glucose uptake and lactate release by isolated monocytes. Monocyte suspensions were incubated at $37^{\circ} \mathrm{C}$ for 90 min (mean $\pm S E M, n=17$ ). Initial medium glucose concentration was $2.5 \mathrm{mmol} / \mathrm{l}$. Glucose uptake $\mathbf{A}$ and lactate release $\mathbf{B}$ are shown. The insulin induced increase in glucose uptake was statistically significant for insulin concentrations higher than $0.01 \mathrm{nmol} / 1(\mathrm{p}<0.01)$ whereas the increase in lactate release was statistically significant for all insulin concentrations tested $(\mathrm{p}<0.05)$

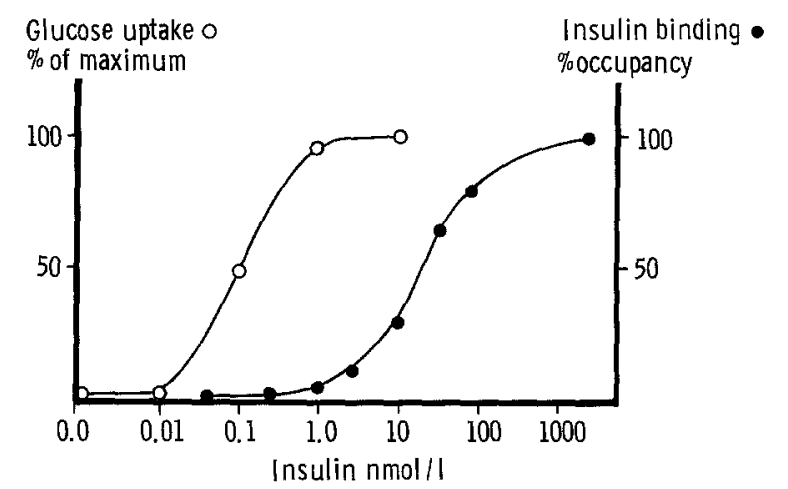

Fig. 7. Dose-response curves for the effect of insulin on glucose uptake and for the insulin binding to monocytes. Glucose uptake ( $\mathrm{n}$ $=17$ ) and insulin binding $(n=5)$ were expressed as percent of maximal effect and percentage of receptor occupancy, respectively. Both variables were determined at $37^{\circ} \mathrm{C}$. For binding studies the monocytes were incubated for $40 \mathrm{~min}$. Only about $10 \%$ of ${ }^{125}$ I-insulin in the medium was degraded at that time

Table 2. The effect of cytochalasin $B$ on the insulin mediated glucose uptake in monocytes. Glucose uptake was measured in monocytes from 3 normal persons (mean $\pm \mathrm{SD}$ ). Insulin concentration was $10^{-8} \mathrm{~mol} / 1$ and the cytochalasin $B$ concentration was $5 \mu \mathrm{g} / \mathrm{ml}$

\begin{tabular}{llc}
\hline & \multicolumn{2}{l}{$\begin{array}{l}\text { Glucose uptake } \\
\mu \text { mol } / 11 \times 10^{6} \text { cells/hour }\end{array}$} \\
\cline { 2 - 3 } & Basal & + insulin \\
\hline - cytochalasin B & $0.47 \pm 0.03$ & $0.60 \pm 0.05$ \\
+ cytochalasin B & $0.15 \pm 0.03$ & $0.21 \pm 0.05$ \\
\hline
\end{tabular}

Insulin stimulation caused a maximal $25 \%$ rise in glucose uptake and a $12 \%$ rise in lactate release (Fig. 6). The increase in both glucose uptake and lactate release was statistically significant. The insulin effect on both variables was dose-related (Fig. 6A and B).

To investigate the insulin effect on the facilitated diffusion of glucose we blocked this process with cytochalasin B. Table 2 shows that cytochalasin B reduced the basal glucose uptake, whereas the insulin stimulated uptake was unchanged (increased about $30 \%$, Table 2).

Figure 7 depicts the relationship between the dose-response curves for insulin binding and glucose uptake in monocytes at $37^{\circ} \mathrm{C}$.

\section{Discussion}

\section{The Monocyte Insulin Receptor Assay}

Because of technical difficulties in obtaining purified preparations of monocytes a mixed suspension of mononuclear leucocytes is commonly used. Using mononuclear leucocytes it is desirable to correct for insulin binding to lymphocytes before adjustment of monocyte binding to a mean concentration of monocytes. In this study we found that the ratio between insulin binding to monocytes and lymphocytes in normals is fairly constant from person to person. Therefore, it is possible with high precision to estimate the insulin binding to monocytes alone from the binding data obtained from a mixed suspension of mononuclear leucocytes [2].

In studies of insulin binding to purified preparations of monocytes, we found that a steady state for the specific insulin binding could be obtained at $15^{\circ} \mathrm{C}$, whereas no plateau was reached at $37^{\circ} \mathrm{C}$ because of a considerable insulin degradation at this temperature. The fall of the binding level at $37^{\circ} \mathrm{C}$ was not as high as expected, which can be explained by intracellular uptake of degraded ${ }^{125}$ I-insulin. Degradation in the medium depends on the insulin concentration. Hence, the insulin degradation is greatest corresponding to the first points on the competition curve and lowest corresponding to the last points. The non-specific binding determined from the last point on the competition curve, therefore, is underestimated. So, at $37^{\circ} \mathrm{C}$ some part of the insulin binding at tracer concentration may be explained by intracellular uptake of ${ }^{125} \mathrm{I}$-insulin. This phenomenon was first demonstrated by Gliemann and Sonne [13] in studies of rat adipocytes.

At $15^{\circ} \mathrm{C}$ the non-specifically monocyte bound fraction was constant during $0-120 \mathrm{~min}$ incubation. 
In contrast, non-specific cell binding increased during the incubation period at $37^{\circ} \mathrm{C}$ in parallel to the increase in insulin degradation. Non-specifically bound ${ }^{125} \mathrm{r}$-insulin at $15^{\circ} \mathrm{C}$ was immediately released to a washout medium. Therefore, this binding fraction can be explained by physical adsorption to the cell membrane and by trapping of labelled insulin in the extracellular water space. So, the non-specific cell binding can be reduced by washing the cells in $4{ }^{\circ} \mathrm{C}$ $\mathrm{NaCl}$ before separation of bound and free insulin.

At $37^{\circ} \mathrm{C}$ two thirds of non-specifically cell bound iodoinsulin was released immediately as nondegraded insulin, whereas the remaining one third was released more slowly. After one hour about $20 \%$ of the released insulin was found to be TCA soluble. We suggest that the non-specifically bound iodoinsulin which can be released within a few minutes may be caused by physical adsorption to the cells plus a small amount of ${ }^{125}$ I-insulin trapped in the buffer among cells. This fraction corresponds to the nonspecific cell binding at $15^{\circ} \mathrm{C}$. On the other hand the fraction of non-specifically cell bound iodoinsulin which was released slowly appears not to be due to a simple cell adsorption. We think that this fraction of insulin might have been taken up into the cells. Gliemann and Sonne's observation that rat adipocytes took up degraded insulin when they were incubated with these products at $37^{\circ} \mathrm{C}$ is consistent with this interpretation.

\section{Insulin Degradation}

In this study we found only an insignificant degradation both of receptor bound insulin and insulin present in the incubation medium at $15^{\circ} \mathrm{C}$, whereas insulin degradation was considerable at $37^{\circ} \mathrm{C}$. At this temperature insulin was degraded in the medium by "proteases" released from the cells, but also receptor bound insulin was a substrate for degradation. We found that prebound iodoinsulin was degraded to a higher degree than the same amount of free iodoinsulin. Furthermore, insulin dissociated from the receptor to a washout medium was degraded even though the activity of insulin degrading "proteases" in the medium was inhibited. Finally, we found that the degradation velocity was proportional to the receptor occupancy. About 35\% of monocyte receptor bound iodoinsulin was released as degraded insulin. When only about $10 \%$ of the iodoinsulin extracted from the monocytes by acid was degraded most insulin must be degraded by dissociation from the receptor. So, at $37^{\circ} \mathrm{C} 35 \%$ of monocyte receptor bound insulin is released as degraded insulin. In rat hepatocytes Terris and Steiner [4] found that about $42 \%$ of total bound insulin (without correction for non specific binding) was released as degraded insulin, while Gliemann and Sonne [13] in rat adipocytes showed that about $50 \%$ of the released insulin was degraded. The finding that receptor bound insulin can be degraded was confirmed by Dial et al. [14] using isolated hepatocyte membranes from mice. Therefore, we can conclude that receptor bound insulin is the substrate for insulin degradation at $37^{\circ} \mathrm{C}$. Thus, in contrast to insulin binding to the monocyte receptor at $15^{\circ} \mathrm{C}$, the binding at $37^{\circ} \mathrm{C}$ is not a simple bimolecular reaction.

We found that about $10 \%$ of iodoinsulin taken up by monocytes at $37^{\circ} \mathrm{C}$ was degraded. Whether this fraction is bound to the receptors or translocated to the inside of the cells, as suggested by Carpentier [15] and Goldfine [16], is a question which cannot be anwered from this study.

\section{Insulin Binding and Insulin Effect}

Glucose uptake and lactate release were highly correlated with the monocyte concentration in the suspension studied. Therefore it is unlikely that the poor contamination with platelets and lymphocytes has any significant influence on the metabolic variables measured. Furthermore, we found the basal glucose uptake in monocytes to be in the same order of magnitude as reported by King et al. [17].

Previously, no insulin effect on monocytes has been reported. In the present study we found that insulin increases both the glucose uptake and the lactate release in highly purified preparations of monocytes. The effect was dose related with $\mathrm{ED}_{50}$-values within the physiological range. In human granulocytes Leroux et al. [18] have demonstrated a similar effect of insulin on glucose uptake (increased 40\%) und lactate release (increased 15\%), while there was no effect of insulin on 3-0-methyl glucose influx or glycogenogenesis. They concluded that insulin increases the glucose consumption in granulocytes by an increase of glycolysis. In monocytes we found that cytochalasin B could not eliminate the insulin effect on glucose consumption, indicating that insulin did not primarily stimulate the glucose carrier. On the other hand lactate production increased after insulin stimulation, but only about $50 \%$ of the glucose taken up was converted to lactate. Therefore, insulin seems to activate other intracellular pathways, too.

From Figure 6 it can be seen that the half maximal biological effect of insulin was obtained by activation of only a few percent of the receptors, whereas maximal effect was obtained by activation of about $25 \%$ of the receptors. These results are in accordance with the findings in adipocytes from rat and mice [19, 20]. 


\section{Conclusion}

Monocytes possess insulin receptors with an affinity constant and a number of sites per surface area in the same order of magnitude as that described in human adipocytes [19]. Furthermore, the glucose metabolism in monocytes is sensitive to insulin. Similar to what has been demonstrated in adipocytes $[19,20]$ and hepatocytes [4] we found that the monocyte receptor bound insulin is substrate for degradation. So, the insulin receptors on monocytes seem to be fairly similar to the insulin receptors on major target cells for insulin action.

Acknowledgements. Dr. J. Gliemann and Dr. Ole Sonne, Institute of Medical Physiology C, Panum Institute, Copenhagen, and Dr. K. Kragballe and Dr. T. Toftegaard Nielsen, County Hospital of Aarhus, are thanked for helpful discussions and valuable advice. T. Skrumsager, L. Busch, L. Blak and J. Jørgensen gave skilful technical assistance. The manuscript was carefully prepared by L. Thomsen.

This study was supported by grants from The Danish Medical Research Council, Aarhus Universitets forskningsfond, NOVO FOND, Nordisk Insulin Fond and Landsforeningen for Sukkersyges Fond.

\section{References}

1. Schwartz, R. H., Bianco, A. R., Handwerger, B. S., Kahn, R. C.: Demonstration that monocytes rather than lymphocytes are the insulin binding cells in preparations of human peripheral blood mononuclear leucocytes: implications for studies of insulin-resistant states in man. Proc. Natl. Acad. Sci. USA 72, 474-478 (1975)

2. Beck-Nielsen, H., Pedersen, O., Kragballe, K., Sørensen, N.S.: The monocyte as a model for the study of insulin receptors in man. Diabetologia 13, 563-569 (1977)

3. Freychet, P., Kahn, R. C., Roth, J., Neville, D. M. Jr.: Insulin interactions with liver plasma membranes. Independence of binding of the hormone and its degradation. J. Biol. Chem. 247, 3953-3961 (1972)

4. Terris, S., Steiner, D. F.: Binding and degradation of ${ }^{125} \mathrm{I}$-insulin by rat hepatocytes. J. Biol. Chem. 250, 8389-8398 (1975)

5. Boyum, A.: Separation of leucocytes from blood and bone marrow. Scand. Clin. Lab. Invest. 21 [Suppl. 197], 77-89 (1968)
6. Brodersen, M. P., Burns, C. P.: The separation of human monocytes from blood including biochemical observations. Proc. Soc. Exp. Biol. Med. 144, $941-944$ (1973)

7. Yam, L. T., Li, C. Y., Crosby, W. N.: Cytochemical identification of monocytes and granulocytes. Am. J. Clin. Pathol. 55, 283-290 (1971)

8. Tennant, J.R.: Evaluation of the trypan blue technique for determination of cell viability. Transplantation 2, 685-694 (1964)

9. Jørgensen, K. H., Binder, C.: ${ }^{125}$ I-insulin as a tracer of insulin in different chemical processes. In: Labelled proteins in tracer studies. Donato, L. (Ed.), pp. 329-333. Brussels: Eurotom 1966

10. Feteris, W. A.: A serum glucose method without protein precipitation. Am. J. Technol. 31, 17-21 (1965)

11. Scatchard, G.: The attractions of proteins for small molecules and ions. Ann. N. Y. Acad. Sci. 51, 660-672 (1949)

12. Hohorst, H.-J.: L- $(+)$-Lactate, determination with lactic dehydrogenase and DPN. In: Methods of enzymatic analysis. Bergmeyer, H. U. (Ed.), pp. 266-270. New York: Academic Press 1963

13. Gliemann, J., Sonne, O.: Binding and receptor-mediated degradation of insulin in adipocytes. J. Biol. Chem. 253, 7857-7863 (1978)

14. Dial, L. K., Miyamoto, S., Arquilla, R.: Modulation of ${ }^{125}$ Iinsulin degradation by receptors in liver plasma membranes. Biochem. Biophys. Res. Commun. 74, 545-552 (1977)

15. Carpentier, J. L., Gorden, P., Le Cam, A., Freychet, P., Orci, L.: Limited intracellular translocation of ${ }^{125}$ I-insulin in isolated rat hepatocytes. Diabetologia 13, 386 (1977)

16. Goldfine, I. D.: Does insulin need a second messenger? Diabetes 26, 148-155 (1977)

17. King, G.W.: Human monocyte metabolism: Male vs. female. J. Reticuloendothel. Soc. 17, 282-289 (1975)

18. Leroux, J.-P., Marchand, J.-C., Ha, H.T., Cartier, P.: The influence of insulin on glucose permeability and metabolism of human granulocytes. Eur. J. Biochem. 58, 367-373 (1975)

19. Andersen, O., Gliemann, J., Gammeltoft, S.: Receptor binding and biological effect of insulin in human adipocytes. Diabetologia 13, 589-593 (1977)

20. Gliemann, J., Sonne, O.: The mechanism of action of polypeptide hormones with special reference to insulin's action on glucose transport. Clin. Endocrinol. (Oxf.) 7, 405-415 (1977)

Received: July 26, 1978,

and in revised form: April 2, 1979

Dr. H. Beck-Nielsen

Medical Department III

County Hospital

DK-8000 Aarhus, Denmark 